\title{
DEVELOPMENT OF A METHODOLOGY FOR CALCULATING OPTIONS FOR THE DEVELOPMENT OF A LOGISTICS NETWORK
}

\author{
Barykin Sergey $E$. \\ Doctor of Economics, Associate Professor, \\ Professor of the Higher School of Service and Trade of \\ the Institute of Industrial Management of Economics and Trade (IPMEiT), \\ Wu Jing \\ Post-graduate student of the Department \\ of Logistics and Supply Chain Management, \\ St. Petersburg State University of Economics
}

Annotation. This article is devoted to the study of methods for solving the problem of increasing the economically sustainable development of international logistics networks, the study of the conditions of capital investments in logistics infrastructure with a positive accumulated cash balance as the accumulated amount of money flows with time stages of planning.

The methodology of T. L. Saati will allow you to combine all the important components (indicators for evaluating the company's performance: ROE, ROA, the ratio of own funds to attracted funds, etc.) into an analytical network.

Key words: analytical network; cash balance; enterprise performance evaluation indicators; energy security; energy supply; environmental friendliness

\section{Introduction}

The Russian trade industry today is in urgent need of finding optimal ways for further active development, accompanied by increased competition in the Russian market, caused, among other things, by the active position of international trade networks with innovative technologies in the field of logistics, which contribute to strengthening the leading positions of innovative and active logistics networks in the conditions of competition not only between Russian networks, but also between global logistics networks. Currently used in Russia, widely known approaches to the organization of trading processes are not effective and do not allow to solve the abovementioned problems, because they can not provide the leading effect in the development of Russian trade areas for the rapid qualitative breakthrough improvement competitive logistics technologies and methodological design of supply chains with the requirements of the external environment to the formation of the logistics infrastructure.

The purpose of this article was the idea of the interdependence of the quality of functioning of the logistics network and the reliability parameters of links international supply chains in the context of studying the ability of logistic network to adhere to the planned level of availability and functionality of transactions in international trade, based on the study of the interdependence of the quality of functioning of the logistics network and the reliability parameters of links international supply chains.

\section{Literary review}

Professor T. G. Shulzhenko revealed the impact of the increase in logistics costs on the return on assets (ROA), calculated as the ratio of gross profit to total assets [8] as well as taking into account the relationship between the return on assets with a total value of logistics costs and the cost of fixed assets [9], [19] the features of global logistics systems and economic actors shaping them; the system of the factors considered in the development of solutions for strategic planning, in particular, the configuration of global logistics systems (GLS). The calculation of options for the development of the logistics network on an international scale should take into account the implementation of customs procedures considered by Professor A.V. Parfenov [14].

A. Fedoseev's opinion about the need to take into account the relationship of the results of the activities of individual divisions with the generalized indicator EVA (Economic value added) is correct [16]. Some authors cited according to management accounting a number of indicators of the enterprises involved in the field of freight LLC "GK NEK" (ROE, ROA, the ratio of own and attracted funds, etc.) [2].

In the process of developing a methodology for designing logistics networks in international trade, scientific publications can find arguments in favor of comparing the structure of a logistics cluster with the DNA model in relation to the design of a cross-border economic cluster [17, p.134]. Developing the idea of the analogy of the development of logistics interaction with the DNA helix, it is interesting to note the approach of comparing innovative development with the DNA helix. An international team of scientists consisting of Loet Leydesdorff, Yevgeny Perevodchikov and Alexander Uvarov analyzed the development of innovation infrastructure and identified insufficient integration of technologically advanced Russian firms [7] based on the methodology of the triple helix of innovation (government, industry, academic environment), developed by the Dutch scientist L. Leydesdorff [4, p.112]. 
On the analogy suggested by Professor A. O. Grudzinsky, "tetrahedron knowledge" [3] on top of which is an innovator in the logistics base of the tetrahedron is a "triangle of interaction of international resource flows of materials, finances and information", and on top of coordinating the interaction between flows and logistics provider.

The spiral of interaction of flows of material, information and financial resources placed in a logistics tetrahedron is coordinated by an integrated logistics provider. The complexity of taking into account the conflicting interests of stakeholders can be reflected in the double prismatic model of correcting the integrity of the branch of the international supply chain (Cherenkov's double prismatic model of logistics management [18, p. 48]).

The law of constancy of the volume of material flow formulated by Professor B. A. Anikin (on the immutability of the physical volume of the elements of material flow in the logistics chain from the producer of commodity products through an intermediary to the consumer) $[1, \mathrm{p} .40]$ can be considered a special case of a more general case in international logistics, which can be formulated as the mandatory continuity of the flow of consumer value in the international logistics network, taking into account the interests of stakeholders.

Professor V. N. Naumov highlighted the prerequisites for strategic interaction in the sales system [12, p. 36-37], which can be extended to the general case of designing a logistics network.

In contrast to partial system analysis, in which only a certain part of the system is examined, logistics design covers the entire logistics system and involves determining the effectiveness of the mutual functioning of all its components [11, p. 625].

Based on the above arguments, we can develop a model based on the methodology of T. L. Saati [15, p. 37], which will allow us to build an analytical network with interdependent criteria, which can be taken as: maximum contribution to the reliable operation of the power plant (energy security), maximum availability of energy supply, maximum environmental friendliness, maximum net discounted income from investment in infrastructure (maximum BPD).

\section{Methods}

A schematic diagram of a warehouse system with several levels of product promotion without a detailed consideration of the relationships in the network design models is considered by Professor Nerush [13], who highlighted the features of infrastructure formation. The influence of the elements of the logistics network in accordance with the causal relationship of the links in the supply chain and the phenomenon of interdependence in general is considered by Professor B. V. Korneychuk [6, p. 37], who defines interdependence in the aspect of improving the quality of life, which characterizes the status or social significance. However, the phenomenon of interdependence is not limited to the degree of impact, it is necessary to consider the interdependence of goals.

In accordance with the proposed logic for determining priorities, the presence of interaction in the analytical network is indicated by the communication arrows (Fig. 1).

In [20], Professor V. V. Shcherbakov considered the application of the idea of adapting the theory and methods of decision-making to the problems of supply chain management. The tasks of supply chain management are interpreted in the context of the organization of paired interactions of participants and the formation of coalition structures. The effectiveness of the Bellman principle and the Pareto principle in making multi-step managerial decisions of a coordination orientation is shown.

The formation of the methodological apparatus for designing a logistics network as a whole can be represented in the form of building a structure of cause-and-effect relationships of strategic goals for designing a logistics network and structure options.

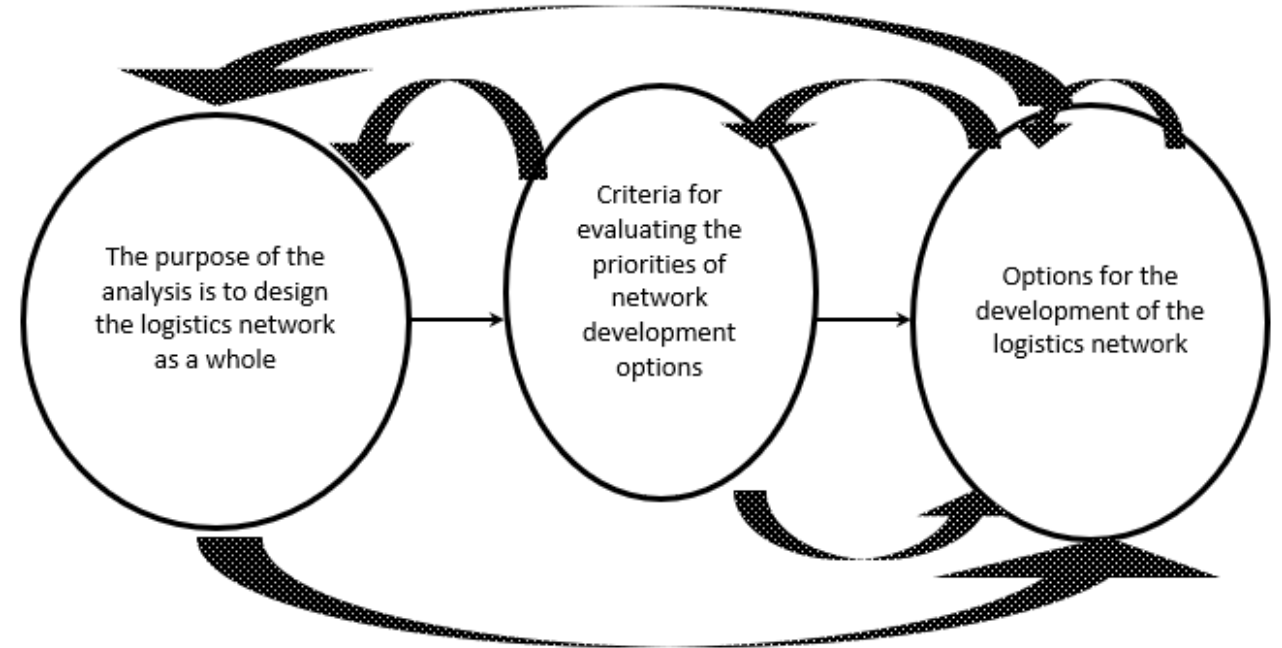

Figure 1. The logic of prioritizing network development options with interdependent criteria 


\section{Results}

A necessary condition for capital investment in logistics infrastructure is a positive accumulated cash balance $O(t)$ as the accumulated amount of money flows $Д_{t}(c)$ by $\tau$ the time stages of planning that precede this interval $(t)$ :

$$
\mathrm{O}_{t}=\sum_{\tau=0}^{t} Д_{\tau}
$$

Let's assume that the basic option chosen for comparison assumes the absence of the construction of a logistics center in Russia and the delivery directly from China to Russia for the assembly and subsequent delivery to Europe of energy equipment. Then, you can consider some indicators for evaluating the effectiveness of investments in logistics infrastructure compared to the basic option: 1) net discounted income from the development of the logistics network; 2) the index of profitability of the development of the logistics network; 3) the internal rate of return on investments in the development of the network; 4) the payback period for capital investments in the construction of a logistics center.

1. Net discounted income from the development of the logistics network (BDD) is determined for each option as the sum of the increments in discounted cash flows at the planning stages during the implementation of measures for the development of the logistics infrastructure:

$$
\text { ЧДД } \text { лс }=\sum_{t=0}^{T} \frac{\Delta \mathrm{U}_{t}+\Delta \mathrm{B}_{t}-\Delta \mathrm{K}_{t}}{\left(1+r_{d}\right)^{t}},
$$

where $\Delta h$ - savings in logistics costs due to the development of the logistics network in year e for each option compared to the basic option (taking into account operating costs (maintenance costs and overhead costs) per year $t$; $\Delta B_{t}$ - revenue increment (for example, for the assembly option in Europe due to a higher degree of confidence in the goods produced in the EU with the corresponding certificates compared to those assembled in Russia) per year $t ; \Delta K_{t}-$ capital investment growth per year $t ; T$-calculation period (the step number for the elimination of infrastructure); $r_{d}-$ discount rate.

2. The yield index (and DLS) is the ratio of the amount of discounted incoming cash flows to the amount of discounted outgoing payments:

$$
\text { ИД }_{л с}=\frac{\sum_{t=0}^{T} \frac{\Delta \mathrm{U}_{t}+\Delta \mathrm{B}_{t}}{\left(1+r_{d}\right)^{t}}}{\sum_{t=0}^{T} \frac{\Delta \mathrm{K}_{t}}{\left(1+r_{d}\right)^{t}}} .
$$

If the value is $И Д_{л с}$ exceeds 1 , then it can be argued that capital investment is effective, with the equality of the

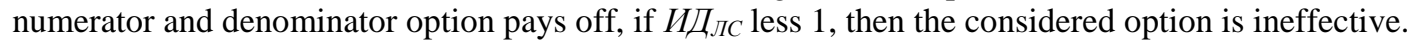

3. The internal rate of return of the option under consideration $\left(В Н Д_{л С}\right)$ represents the discount rate $\left(r_{0}\right)$, at which the value of discounted cash incoming flows is equal to the value of discounted outgoing payments. When substituting instead of the discount rate $r_{d}$ in the expression (1) substitute $r_{0}$ meaning ЧДДлс becomes equal to zero. ВНДЛС is the solution of the following equation:

$$
\sum_{t=0}^{T} \frac{\Delta \mathrm{h}_{t}+\Delta \mathrm{B}_{t}-\Delta \mathrm{K}_{t}}{\left(1+r_{d}\right)^{t}}=0
$$

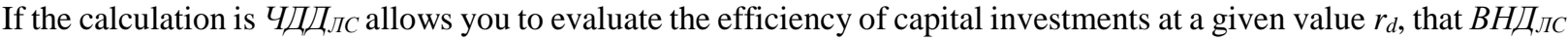
characterizes the sensitivity ЧДДЛС to change the value $r_{d}$ and is compared with the return on investment corresponding to the interests of stakeholders.

4. The payback period is the number of years when the initial investment and the increase in costs are compensated by the results of the implementation of investments in the development of the logistics network. According to the Methodological Recommendations of June 21, 1999 [10], the payback period is the number of years when the accumulated amount of the balance becomes and remains non-negative in the future.

\section{Discussion}

When developing a methodology for calculating options for the development of a logistics network, it is necessary to proceed from the desire to fully meet the needs of customers, taking into account the interests of stakeholders and the measures to coordinate the supply chain that need to be performed.

The study of the relationship between the concept of reliability and improving the quality of the logistics network in international trade allows us to take into account the threefold nature of logistics systems for the supply of energy equipment in Europe (energy security, accessibility and environmental friendliness) as socio-economic customer-oriented systems. In this way, feedback is achieved between the results of the infrastructure assessment and the effectiveness of the logistics network, taking into account the interests of stakeholders, including from the point of view of the value 
contribution to the development of corporate culture [5, p. 75], the concept of which is applicable to the global supply chain from a corporate perspective.

\section{Conclusion}

The developed method of calculation of indicators for assessing the effectiveness of investment in logistics infrastructure shows the interdependence of the quality of functioning of the logistics network and the reliability parameters of links international supply chains in the research process, the ability of logistic network to adhere to the planned level of availability and functionality of transactions in international trade that allows you to design the structure of supply chains in international trade based on the system of principles of development, taking into account the interests of various stakeholder groups.

\section{Literature}

[1] Anikin B. A., Tyapukhin A. P. Commercial logistics. - M.: Prospect, 2005.

[2] Bushuev A. How to prepare for a job in a logistics company / / Financial Director. - 2012. - №3 (114) . - P.76-79.

[3] Grudzinsky A. O., Bedny A. B. Kontseptsiya konkurentnogo universiteta: modeli tetrahedra [The concept of a competitive university: a tetrahedron model]. - 2012. - No. 12. - p . 29-36.

[4] Itskovits G., Leidesdorf L. Dynamics of innovation: from national systems and "Regime 2" to the Triple spiral of university-industry-state relations // Research policy. - 2000. - No. 29. - pp. 109-123.

[5] Kapitonov E. A., Kapitonov A. E. Corporate culture. Monograph. - M.: JSC Rostizdat, 2001. - 384 p.

[6] Korneychuk B. V. Human capital in the time dimension. Transformational models of microeconomics. - St. Petersburg: "Severnaya Zvezda", 2004. - 196 p.

[7] Leidesdorf L., Perevodchikov E., Uvarov A. Measuring the synergy of the triple helix in Russian innovation systems at the regional, provincial and national levels. - 2015. - №6(66). - Pp. 1229-1238.

[8] Lukinsky V. V., Shulzhenko T. G. Integral assessment of logistics activity efficiency using key indicators // Logistics and supply chain management. - №6 (47). - 2011

[9] Lukinsky V. S., Shulzhenko T. G. Evaluation of the effectiveness of investments in logistics infrastructure on the basis of the integral method of economic analysis. Logistika: sovremennye trendiy razvitiya: materialy XI Mezhdunar. Nauch. - prakt. konf. 19, 20 April 2012 / ed. kol.: V. S. Lukinsky (ed.) [et al.]. - St. Petersburg: SPBGIEU, 2012. - 472 p.

[10] Methodological recommendations for assessing the effectiveness of investment projects (Second edition, corrected and supplemented) (approved by the Ministry of Economy of the Russian Federation, the Ministry of Finance of the Russian Federation and Gosstroy of the Russian Federation dated June 21, 1999, No. VK 477), hands. author. Col.: Kossov V. V., Livshits V. N., Shakhnazarov A. G.-M.: JSC " NPO "Publishing House "Economy", 2000 - - 421 p.

[11] Murphy, Paul R. Interaction management in the sales system: theory, methodology, strategies [Text] / Murphy, Paul R., Wood, Donald F. ,- 8 ed. - Moscow: LLC "I. D. Williams", 2016.

[12] Naumov V. N. Interaction management in sales and distribution: theory, methodology, strategy [Text] / - SPb. OOO "Polytechnic", 2011.

[13] Nerush, Y., gentry, C., Nerush, A. Designing logistics systems: tutorial and workshop / Y. Nerush, S. Panov, A. Nerush. - M.: Yurayt, 2015. -422 p.

[14]Parfenov A.V. Features of the application of customs logistics technologies in the framework of the single economic space [Text] / A.V. Parfenov, A. N. Morozov / / Logistics. - 2012. - No. 4. - p. 26-28.

[15] Saati T. Decision-making with dependencies and feedbacks: Analytical networks. Per. s engl. / Scientific ed. A.V. Andreychikov, O. N. Andreychikova. - M.: Publishing house LKI. 2008. - 360 p.

[16]Fedoseev A. / / How to manage the cost of a company with the help of budgeting / / Financial Director. - No. 4 (115) April 2012. - p. 26-31.

[17] Freidman O. A. The process of designing a logistics cluster based on a problem-oriented approach and the method of analogies // Proceedings of the Volgograd State Technical University. - 2015. - №3(158). Pp. 127-134.

[18]Cherenkov V. I. Osnovy mezhdunarodnoy logistiki: uchebno-metodicheskoe posobie [Fundamentals of international logistics: an educational and methodological manual].

[19] Shulzhenko T. G. Theoretical aspects of designing the structure of the global logistics system. In the collection: Modern management: problems and prospects Collection of articles: in two parts. - 2016. - p. 535-539

[20] Shcherbakov V. V., Saprykin I. G. Ideas of adaptation of the theory and methods of decision-making to the problems of supply chain management. 2010. No. 4. - pp. 215-216. 